\title{
ON THE USE OF ARCHAEOLOGY AND HISTORY IN ISLAND SOUTHEAST ASIA
}

\author{
BY
}

\author{
PETER V. LAPE*
}

\begin{abstract}
This paper reviews the use of archaeological and documentary sources in the understanding of the past in Island Southeast Asia. The relationship between these two sources of data (and data sources that cross the boundaries of these categories) has varied over time, depending on the availability of data, changing interpretive strategies and scholarly trends and influences. The wealth of documentary sources relevant to Island Southeast Asia's past, and the increasing availability of detailed archaeological data have increased the potential to understand the past in this region from a variety of points of view. While this potential has not yet been fully realized, in part due to an unsophisticated use of these separate lines of evidence, recent scholarship has pushed the boundaries and revealed new information and insights into this history.
\end{abstract}

Cet article passe en revue l'utilisation de sources documentaires et archéologiques dans la connaissance du passé des îles du Sud-Est asiatique. La relation entre ces deux sources d'information (et les sources qui dépassent les limites de ces deux catégories) a évolué au fil du temps en fonction de la disponibilité des données, des changements dans les stratégies d'interprétation et des tendances et influences académiques. La richesse des sources documentaires utiles dans l'étude du passé des îles du Sud-Est asiatique, et la disponibilité croissante de données archéologiques détaillées ont permis, à plusieurs niveaux, de faciliter la compréhension du passé de cette région. Bien que ce potentiel n'ait pas encore été complètement exploité, en partie à cause d'une utilisation peu raffinée de ces distinctes catégories de preuves, des études universitaires récentes ont repoussé ces limites et ont dévoilé de nouveaux indices, permettant ainsi de mieux pénétrer l'histoire des îles du Sud-Est asiatique.

Key Words: Historical archaeology, Island Southeast Asia, Banda Islands, foreign trade, Islam

\section{INTRODUCTION}

The relationship between material and textual data sources in investigating past human cultures has long been an explicit concern for scholars. Since archaeologists are typically more likely than historians to collect and interpret both kinds of data in their raw forms, they have also been the source of most of the scholarship on the relationship between the two kinds of data. The use

\footnotetext{
* Peter V. Lape, Department of Anthropology, University of Washington, Seattle, WA 98195, plape@u.washington.edu
} 
of archaeological and documentary data in Island Southeast Asia has had its own particular trajectory of scholarship. This history of scholarship has been defined, as in other regions, by the nature of archaeological sites, their accessibility to certain restricted groups of archaeologists, as well as the sources and availability of textual sources. Below is a review of these region-specific disciplinary paths, a description of the unique nature of textual and material evidence related to Island Southeast Asia, and contextualization of the historical archaeology of the region in global scholarship.

\section{DOCUMENTS AND MATERIAL REMAINS: WHERE ARE WE NOW?}

Archaeologists and historians have used a combination of documents and material remains to investigate and interpret the past from the beginnings of the disciplines. While these two types of data require different research methods, some scholars have developed the required skills to work with both. More typically, however, historians and archaeologists have relied on each other to do the initial data recovery and interpretation, and worked with secondary sources for areas outside of their particular disciplinary boundaries. The increasing specialization in academic scholarship has had the effect of further limiting the crossing of disciplinary boundaries. Few scholars who identify themselves as "archaeologists" can be found working in archives, and even fewer "historians" can be found excavating archaeological sites.

The development of "anthropological" archaeology in the US and Europe has also contributed to this disciplinary split. While classical archaeology is rooted in art history, and typically requires its practitioners to be well versed in the documentary record of the classical world, anthropological archaeology began with a specific focus on the "prehistory" of non-literate groups. The explicitly scientific and generalizing orientation of the New Archaeology of the 1960s largely rejected the "culture history" of earlier archaeology in favor of the investigation of cultural processes (Flannery 1972; Trigger 1989). One effect of this has been to both demand more time for training in natural scientific methods and de-emphasize the usefulness of written documents, with their specific and temporally narrow cultural data.

However, a cross current in anthropological archaeology was the simultaneous development of historical archaeology. While this subdiscipline has been subjected to varying definitions and restrictions by its self identified practitioners (Andren 1998; Schuyler 1978), most historical archaeologists see themselves as archaeologists first, who also use the texts written by and/or about the people who's past they are studying. The subdiscipline of historical archaeology (which can be viewed as a mosaic of other more specialized traditions such as medieval 
archaeology, culture contact archaeology, colonial archaeology, etc.) has also had internal divisions that mirror those in anthropological archaeology, such as between an emphasis on culture history and process, science, post modernism, etc. (M. Hall 2000; Kirch and Sahlins 1992; Knapp 1992; Leone and Potter 1988; Lightfoot 1995; Orser 1996; Rogers and Wilson 1993; Schuyler 1988; South 1977). Anthropological archaeology today incorporates all of these historical trends, as well as some new attempts to move past their theoretical limitations. Both older culture history and more recent culture process orientations continue to be represented in the literature (with culture history perhaps more common in American historical archaeology and cultural resource management research). Some have called for a holistic approach that incorporates both particularistic studies and cross-cultural generalizing ones (Trigger 1984; Trigger 1989). Archaeologists have looked to historians who are sympathetic to generalizing approaches (such as those in the Annales school) for models of incorporating particularistic textual data into variable temporal scales typical of archaeological research (Bintliff 1991; Knapp 1992; Last 1995). Unfortunately, much of this attempt to integrate archaeology and history would appear to relegate archaeology solely to the longue durée, ignoring the potential relevance of archaeological data to shorter terms, or even events. However, they have highlighted the potential of longterm culture history to provide general conclusions that are applicable crossculturally.

These myriad influences and cross currents, along with broader debates in the humanities and social sciences, have all influenced the ways scholars have used texts and material remains in combination. These influences have been analyzed extensively in other publications, some with book length treatments, and I will not attempt to review them all here (Andren 1998; Beaudry, Cook, and Mrozowski 1991; Bintliff 1991; Boyd, Erwin, and Hendrickson 2000; Faubion 1993; Kepecs 1997; Kirch and Sahlins 1992; Leone and Potter 1988; Lightfoot 1995; Schuyler 1978; Schuyler 1988; Trigger 1989; Young 1988). Another topic of concern that I will not attempt to review closely is the role of oral history, tradition and myth in combination with archaeology (Kus 1997; McBride and Rudden 2000). However, I will discuss some currents of debate that appear to me to be most salient for the discussion of the use of texts and material remains in Island Southeast Asia. These include assigning the appropriate interpretive "weight" to each body of data and different strategies for combining the disparate data obtained from texts and material remains to create interpretations that transcend the individual limitations of each kind of data. 


\section{ASSIGNING INTERPRETATIVE WEIGHT, TRANSCENDING TYRANNY}

The famous epitaph that historical archaeology is an expensive way to find out what we already know about the past sums up one critique of archeological studies of periods from which we have written texts. Historical archaeologists typically see this statement as an example of a pervasive "tyranny of the text" in academic and popular culture (Champion 1990; Thurston 1997). They echo an earlier call by New Archaeologists for archaeology to free itself from misleading conclusions derived from culturally constructed history (Binford 1962; Clarke 1973). This view holds that western academic culture (which is populated by individuals who gain their authority and status largely from reading and writing texts) places too much emphasis on writing, and not enough on material objects. Euro-American culture in general often confuses writing for truth. In this view, we do not "already know" everything even if we have extensive texts, and archaeological data can provide an alternate point of view (Kirch and Sahlins 1992; Leone and Potter 1988). This alternate point of view has the potential, for example, to give a historical voice to those people traditionally missing from the documentary record: the colonized, the poor, the less educated, illiterate, and "those of little note" (Ferguson 1992; Scott 1994). Archaeological data can therefore fill gaps in our knowledge, somehow making historical studies more "complete."

If we accept that archaeological data has a valuable contribution to make, we are still left with the problem of how to weigh these different types of evidence, particularly when they appear contradictory. On one side, some historical archaeologists (echoing both Binford and Foucault) claim that written sources, particularly those from colonial contexts, are ideologically tainted, and the archaeology of material culture provides the only portal to a non-ideological "truth" (Rubertone 1989; Trouillot 1995). Others use textual data to construct hypotheses that can then be "tested" against archaeological data. This method allows for contradictions to be highlighted, which can often provide insights into the cultural production of texts. However, debate continues on how methodologically separated the two lines of evidence actually are in constructing "hypotheses" and "tests." Some types of data, such as inscriptions, actually fall between; they are both texts and artifacts, and require the use of both historical and archaeological methods (Morrison and Lycett 1997). Methodological separation is an important part of source criticism, and remains an area of concern (Andren 1998; Feinman 1997; Kowalewski 1997). 


\section{BEYOND ARTIFACTS AND TEXTS}

Although the process of assigning the appropriate weight and methodological status to textual vs. material evidence remains unclear, what is clear is that the two kinds of evidence used together can provide more interpretive power than either used alone. For example, while archaeologists and historians had worked separately on the problem of Danish state formation (AD 800-1050), they had come up with different conclusions regarding the chronology and spatial extent of political integration. Thurston's study unified these previously contradictory models in a way that showed both to be "true"; discrepancies between the data mirrored actual conflicts during this period of social transformation to statehood (Thurston 1997). Others have used texts and materials to extend the dynamics of the "historical" period into the artificially static "prehistoric" past through analogy (Deagan 1988; Kolb 1997; Lightfoot 1995). This line of thinking is an important component of so-called "holistic" or interpretative archaeology, which seeks to re-introduce culture history into archaeology, and at the same time introduce the longue durée into history, while incorporating theoretical and/or comparative perspectives.

The common themes linking much recent scholarship in historical archaeology, including that discussed above, are discussions of ways to move beyond the "tyranny of texts" and master narratives about the past, which are seen as lacking interpretive power to explain the incredible diversity of human responses to historical situations. For example, some archaeologists have called for a new historical archaeology that looks "back from the edge" (Funari and Hall 1999). Among the many things that this means is the idea that it is possible to transcend the disciplinary oddities of American archaeology, such as those mentioned above, and consider local histories as framing narratives on an equal basis with European histories. For example, local histories need not be "about" the rise of capitalism and world systems, or the age of exploration, but rather can be seen as driven by local motives and situations, influenced in varying degrees by world events filtered through local actors. This can be seen as part of a larger movement to decentralize historical scholarship (Clarke and Torrence 2000; Cusick 1998b; Gosden 1999; Orser 1994; Rowlands 1998; Schmidt and Patterson 1995). A running theme in this movement is an attempt to both shift control of the production of archaeological knowledge to local or indigenous people, and by doing so, make archaeological knowledge relevant to those people (Layton 1989; Miller 1980; Moser 1995). 


\section{HISTORY/ARCHAEOLOGY IN ISLAND SOUTHEAST ASIA}

Documentary and material data have long been used jointly to investigate Island Southeast Asia's past (Island Southeast Asia is considered here to include the nations of Indonesia, the Philippines, Singapore, insular Malaysia and East Timor; see Figure 1). Sir Thomas Raffles, for example, utilized epigraphic references and descriptions of ancient monuments to create his History of Java in the early 19th century (Raffles 1817). Raffles' work inspired a new interest in the antiquity of the monumental architecture of Java, and the excavation of several temple complexes and translation of their inscriptions. This work was done almost exclusively by European colonial scholars and administrators, and throughout the Dutch colonial period, history and archaeology in Indonesia was characterized by a colonialist perspective, which emphasized foreign "civilizing" influence (in this case primarily from India and the Arab world), and de-emphasized indigenous ingenuity (Tanudirjo 1995; Trigger 1989: 110-147). The colonialist approach was also evident in studies relying primarily on documentary data, despite the fact that some of the documents were evidently written by Indonesians (Schrieke 1960; Wisseman Christie 1995).

A representative example of the changing uses of documents and material data to investigate the past in Island Southeast Asia is the evolving theories of the rise of "kingdoms" and other forms of complex polities. Archaeologists currently see the development of social "complexity" in the region, such as the development of chiefdoms and early states, as linked to the growing importance of maritime trade and resulting cultural influences and contacts from the outside world, primarily China and India after 2500 BP (Wisseman Christie 1995). The earliest surviving written documents that describe Island Southeast Asia date to this period, and include both texts written by "foreign" observers from China and India, and, later, "indigenous" texts, the earliest surviving examples being stone inscriptions. These texts definitively describe Island Southeast Asia as a zone of cross-cultural interaction. As early as $2000 \mathrm{BP}$, these documents strongly suggest that there were communities in Island Southeast Asia that were regularly visited by traders from distant places (Ray 1989; Rockhill 1915). Archaeologically, there is also definitive evidence of this interaction, including trade goods from mainland Asia and the subcontinent, and similarities in art and architectural styles, particularly with Hindu-Buddhist temple styles replicated in western Indonesia (Glover 1990).

While much historical and archaeological research in Island Southeast Asia has followed theoretical trends developed in other regions, there are some examples where the regional data has inspired theory building. One example is the 


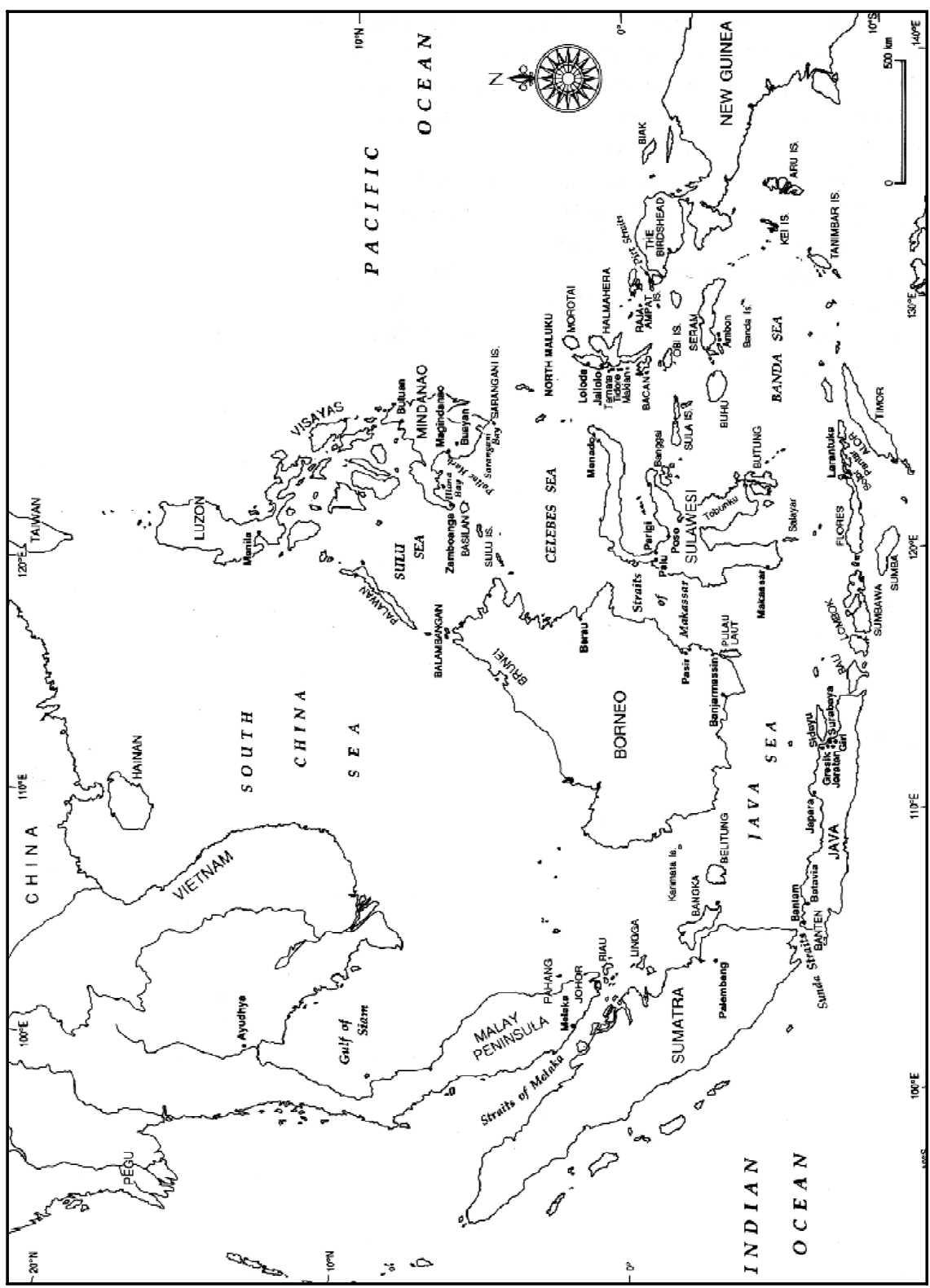


ongoing debate on "Indianization." The traditional view has been that state formation in Indonesia required the import of people and ideas from India (Coedés 1968). Other theorists, such as van Leur (1967), proposed the then radical theory that Indonesians took an active role in the process of state formation, although even he still believed that the one-way transmission of ideas from India to Indonesia was an essential catalyst. More recently, and as more data from both India and Indonesia became available, some theorists have proposed a two-way exchange of ideas, technology and personnel (Wolters 1999). Kulke (1990) proposes a "convergence hypothesis" that uses new data on state development in the Bay of Bengal region of India, which had the most direct contact with Island Southeast Asia during the early stages of state formation. Kulke uses precise dating of architectural style shifts in both regions to demonstrate that states developed in both regions at about the same time, and that influences on architecture traveled in both directions (Kulke 1990). This theoretical shift, from a focus on outside "civilizations" to internal forces as the source of cultural innovation is mirrored in theoretical shifts away from acculturation in general culture contact theory in other parts of the world (Cusick 1998a). Features of this shift include a focus on the two-way transfer of ideas, influences and technologies in culture contact situations, an increased concern with the specific mechanisms of information transfer and a focus on local uses and meanings of foreign ideas and material objects. This theoretical shift provides an interesting comparison with the situation in North American archaeology. It seems that internal innovation was emphasized in regions like Indonesia that gained independence from colonial powers in the 1940s, before it became fashionable in North America, where Native American societies continue to exist in a colonial situation (MacKnight 1986; Wisseman Christie 1995).

There are several examples of innovative uses of documents and material remains in the region. Laura Junker has also combined documentary and archaeological sources in her studies of social complexity and trade in the Philippines from the 10th-17th century AD (Junker 1993; Junker 1994; Junker 1996; Junker 1998; Junker 1999). In her work, Chinese, Arab and Spanish texts and Malay oral traditions provide disparate narratives about the nature of foreigner interactions and political developments. These are compared with a relatively large set of archaeological data from the same time period regarding local and long distance trade and social organization at a variety of spatial scales. Contradictions between texts serve to both expose biases and illuminate the context of their production, and ultimately to provide an analytical portal to generate questions for the archaeological data. The result is a rich description of Philippine political development that allows for anthropologists to compare Philippine chiefdoms 
with other chiefdom-like societies while avoiding the "overhomogenization" that often results from attempts at broad comparison (Junker 1998: 292), while also adding to regional culture history and informing other studies (Bacus 1999; Skowronek 1998).

In Indonesia, a few historical archaeology projects have also contributed to both regional and global anthropological theory. Bulbeck and Caldwell have used Bugis texts in conjunction with archaeological settlement and mortuary data to investigate shifts to chiefdoms as a result of Bugis colonization of the Luwu region of South Sulawesi (Bulbeck 1992; Bulbeck and Prasetyo 2000; Caldwell 1995). In this case, Caldwell's analysis of Bugis texts provided a starting point for Bulbeck's archaeological research, which also incorporated consideration of oral history, myth and ethnographic analogy. While not clearly methodologically separate from textual analysis, the archaeological questions derive from and in some cases depart from historical analysis. For example, while Bugis texts and mythology suggest that their colonization of Luwu was a transformative "event" that revolutionized the region politically, archaeological data suggest that the Bugis brought nothing new to the region, which had long been involved in long distance trade. By re-reading the texts and myths (such as $L a$ Galigo) against the new archaeological data, Bulbeck concludes that the originating force behind the texts and myths was the need to define Bugis status, which required promulgating heroic stories of Bugis political and economic prowess (Bulbeck and Prasetyo 2000).

In some parts of Island Southeast Asia, archaeologists continue to search for material expression of the complex polities described primarily in texts by foreigners such as the Chinese. In the Philippines, Junker (1994: 250-252) concludes that the discrepancy between Chinese descriptions of elaborate and wealthy "kingdoms" in Tanjay and archaeological remains of somewhat more modest settlements is a result of the exaggeration of the scale of polities by the ruling elite. In western Indonesia, where this discrepancy also apparently exists, archaeologists have generally accepted the textual and epigraphical data at face value, and have looked for alternate explanations to explain the discrepancies, with the result that considerable theoretical progress has been made (though real data remain somewhat scarce). For example, much work has been done on developing locally appropriate models for state development (Edwards McKinnon 1984; Hall 1985; Wisseman Christie 1995; Wolters 1974), and on post depositional and landscape factors that might reduce the archaeological visibility of certain sites (Allen 1991). Others have questioned the role of cities and urbanism as a necessary feature of states in Island Southeast Asia. Miksic, for example, suggests that dense settlement characteristic of urban areas may not have 
been possible in the humid tropics until technological solutions were found for problems with water supply and waterborne diseases (Miksic 1999; Miksic 2000).

The study of the processes by which Islam became the dominant religion in much of Island Southeast Asia provides a somewhat different perspective. While it is clear that the foundations of the Islamic belief system originated in regions far removed from Island Southeast Asia, Muslim identity and practice in the region was seen as locally distinctive by the earliest foreign observers. Unlike traditional views of early state development, the growing presence of Islamic thought and practice in Island Southeast Asia has always been described, at least by outside observers, as partly a local invention, with a continuous influence of non-Islamic indigenous belief systems. Even the earliest texts describing Muslim practice in Island Southeast Asia tended to emphasize its difference from Muslim practice in the Middle East. Early Arab visitors to the region were often appalled by unorthodoxies (Tibbetts 1979), while early European visitors, who may have been looking for excuses to engage in trade with Southeast Asians in an anti-Islam political climate in Europe, were less judgmental but equally curious about different practices (Pires and Rodrigues 1944; Reid 1993a). This descriptive pattern is continued in western academic analyses (Bowen 1989; Feener 1998; Geertz 1960; Hooker 1983; Milner 1983; Ricklefs 1993; Ricklefs 1979), and may reflect an attempt by western scholars to differentiate Southeast Asian "liberal Islam" from threatening fundamentalist forces in the Middle East.

Many studies by historians and cultural anthropologists have brought into focus the different ways individual actors strategically utilized and manipulated available religious dogma, including fundamentalist Islam, Hindu-Buddhist thought, ancestor worship and animism (Anderson 1990; Geertz 1960). Most western academic historians of Island Southeast Asian Islam depict history in terms of these kinds of processes. Johns (1995), for example, has reevaluated the role of the Sufi mystic, particularly in spreading a text-centered religion like Islam through the largely non-literate world of 13th-17th century Island Southeast Asia. In the framework of culture contact theory, this concern with local difference could be seen as innovative. However, as studies of the history of Islam in Island Southeast Asia have been almost entirely dependent on documentary evidence, this concern can be attributed to the reflection of biases inherent to the data. Some researchers have worked to transcend these biases by critically analyzing local texts within local contexts through lenses of local politics and history or relationships to the diversity of Muslim practice in other places (Feener 1998; Hooker 1983; Johns 1995). 
The power of archaeological data to provide an alternative line of evidence that is independent of documents produced during the politically charged interaction between Islam and Christianity in the early modern era has not yet been fully realized. It may have a significant role in the future. Archaeological data has been used to interpret the Islamization process in other parts of the Muslim world (for example, Insoll 1996; 1999). The relatively few archaeological studies that address Islamization in Island Southeast Asia suggest that the history of the process is considerably more complex than can be inferred from the written record. My own research on the role of Islam in Eastern Indonesia provides an example of the ways in which archaeological data used in conjunction with texts can provide key insights into these cultural processes.

\section{CASE STUdy: Foreign TRADE AND ISLAM IN THE BANDA ISLANDS}

My own research has centered on questions of cross-cultural interaction in eastern Indonesia during the 10th-17th centuries. The case study presented below concerns the relationship between foreign trade and settlement patterns in the Banda Islands (see Figure 2). These eleven islands were once the world's sole source of nutmeg and mace, and were visited by long distance maritime traders from insular and mainland Asia and the Middle East for at least two millennia. Muslim traders brought ideas as well as trade goods, and by the mid-15th century, many Bandanese considered themselves Muslims. In the 16th and 17th centuries, the islands became the site of some of the fiercest struggles for trade and colonial dominance in the early modern era. The Banda Islanders first encountered Europeans in $1512 \mathrm{AD}$, with the arrival of the first Portuguese trading ships. Just over a century later in 1621, the Banda's were irrevocably changed when Dutch East India Company (VOC) forces, aided by Japanese mercenaries, massacred, enslaved or banished some $90 \%$ of Banda's population. Dutch farmers and their Asian slaves subsequently repopulated the islands, the first footholds in what became the Dutch colonial empire in the East Indies (Hanna 1978; Loth 1995a; Loth 1995b; Loth 1998; Masselman 1963; van der Chijs 1886).

In this case, research was directed towards questioning received wisdom about "foreign" influence in Banda, in particular the Islamization process. I used a combination of archaeological and textual data to establish a chronology of changing long distance trade patterns and to map the locations of foreign trade ports. The combined data were used to analyze how Bandanese society changed as foreign trade volume and intensity increased, particularly during the 14th17th centuries leading up to the Dutch colonial conquest. Combining the data also provided insight into the cultural production of those texts and maps, and added the dimension of those who were not recorded in written history. Banda 

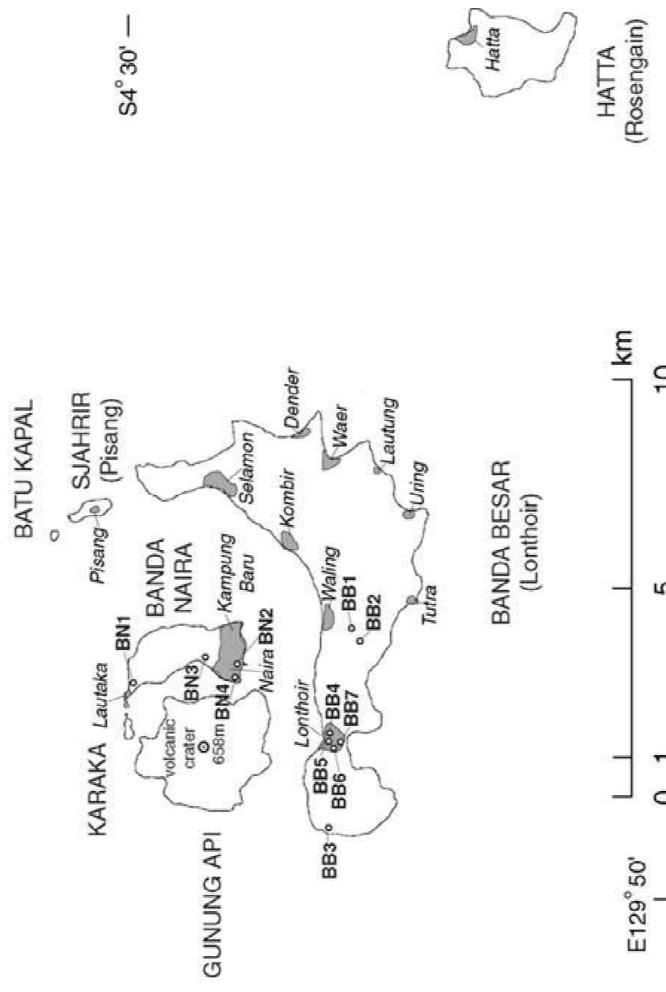

$\underline{\underline{s}}$

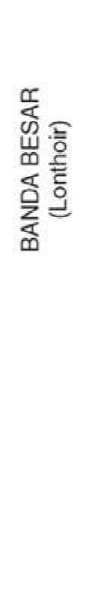

토
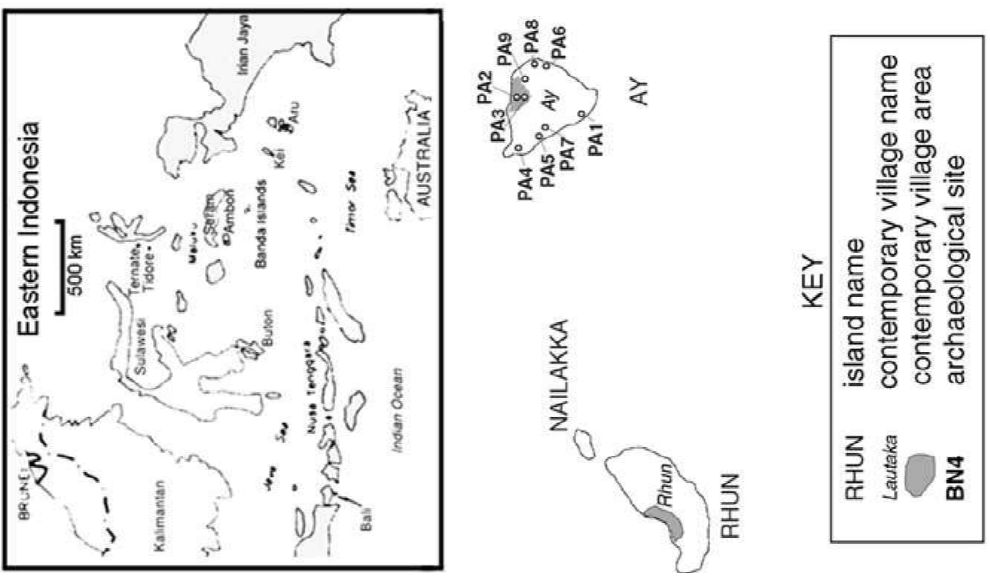
archipelago settlement patterns were chosen as an aspect of Bandanese society that could be investigated using both textual and archaeological data, and that could also illuminate other social changes that could be investigated in subsequent studies, such as those at the household or village level. These results have been described in detail in other publications (Lape 2000a; 2000b; 2000c; in press), but will be briefly reviewed here.

\section{Textual Data}

Textual data available for this research included a variety of descriptions, maps and images of the islands recorded by foreigners, including Chinese, Javanese, Arab and various European travelers and traders. Maps were a particularly useful set of data, although only maps drawn by European visitors after 1512 were located in archives. The motivations behind the making of maps were (and still are) multiple and sometimes conflicting. In many cases, maps were made to help future travelers find their way. For traders, the names and locations of principal market or trading towns were crucial. However, maps also served political purposes, and for these reasons the information on maps may have been deliberately misleading. For example, trading companies may have hidden the location of potentially profitable trading locations to gain an advantage over competitors (Harley and Woodward 1987; Suarez 1999; Zandvliet 1998). As these companies were entangled in national interests, they may have altered the geographical location of places to bring them under their political realm to conform to existing treaties. Treaties made with native groups may have also influenced map making. Groups or settlements that refused to sign over monopoly privileges may have been excluded from maps to make it seem as though there was unanimous consent for such treaties (for other colonial situations see Fisher and Johnston 1993; Galloway 1995; Stahl 2001). Areas that resisted foreign control or allied with an enemy may have been shown as empty, devoid of settlement, in some cases simply because a mapmaker was denied access to them (Trouillot 1995; Winer 1995).

Other unintentional errors creep into the texts written on maps. The transcription of unfamiliar languages into European phonology may have meant that places with unpronounceable names (for Europeans) were altered. Because maps of Banda were often made after rather short visits to the islands, misunderstandings, incomplete knowledge and confusions may have altered the place names we now see on old maps. Places in Banda probably had multiple names in the past as they do today, including sacred names and names for everyday use. Language change on Banda itself, stimulated by the increasing numbers of foreigners who settled there, may have altered place names over time. The fact 
that Europeans gained information through non-indigenous intermediaries such as Turks, Malays or Javanese, all of whom spoke different languages than the native Bandanese, probably altered the toponyms that have been recorded on maps (Description 1598; Tweede 1601; Valentijn 1724; Wall 1928).

There are dozens of potential biases that could have altered maps from a "true" representation of the physical space of Banda. However, these biases do not simply make the maps less accurate. Geographers and historians have successfully deconstructed maps and teased out new insights into the "social world in which [they] were produced" (Harley 1992: 232). Historical archaeologists have similarly used maps as one set of documentary data to cast against other kinds of data as a sort of test or comparison (such as Hall 2000; Winer 1995). By contextualizing and comparing maps of late precolonial Banda with other maps and the documentary and archaeological record, they can help us understand the mindset of European visitors to Banda, and the cultural process at work there. What mapmakers saw and how they conceived of the geographical space of Banda was, in part, determined by and determinant of the cultural encounter between the various European and Asian groups present in Banda. When compared against the archaeological record, many biases can be exposed, and their power as data considerably enhanced.

In the course of archival research I located 15 different maps depicting the pre and early colonial Banda Islands that had settlement-level detail, dating from 1570-1680. These were located in a wide variety of private collections, archives and published sources, and are discussed in detail in my dissertation (Lape 2000b). Five of those maps are discussed here to illustrate their use in conjunction with archaeological data. The first appearance of Banda on surviving world maps dates to an anonymous mappamundi of 1457, which was probably informed by the account of Nicoló de'Conti, who claimed to have visited the islands (Suarez 1999: 79). Another early map showing Banda is the Rodrigues Map, which was probably copied from an Asian-drawn map used by the first Portuguese expedition to the islands in 1512 (Cortesão and Mota 1987: pl. 22; Lape 2000b: 84-85; Nakamura 1963: 28-32; Sollewijn Gelpke 1995); however, neither of these maps show individual settlements. The earliest map to do that in detail is the van Neck Map, which was first published in 1601, immediately after the Dutch expedition commanded by Cornelius van Neck returned to Holland from Banda and the East Indies. This particular map was probably the first detailed map of the Banda Islands published in Europe, and it became extremely influential on subsequent mapmaking and European ideas about the configuration of the islands (see Lape in press for a detailed analysis of historic maps of Banda). 


\section{Archaeological Data}

In 1997-98, I conducted archaeological survey and excavations at various late pre-colonial sites on three of the Banda Islands aimed at locating settlements, determining their occupation chronology and describing settlement level features, such as exotic trade good presence, settlement-wide foodways and architectural features, particularly fortifications. Research objectives were to collect chronological data on settlement pattern changes, and to investigate whether individual settlements were distinctive in terms of material markers of behavior and settlement history in the five centuries leading up to the conquest of the islands by VOC forces in 1621. Archaeological survey, excavation and most artifact analysis were conducted during two field seasons. A full coverage settlement analysis was not attempted (compare Fish and Kowalewski 1990), given the short time frame available and conditions that made systematic site survey impossible.

Rapid sediment deposition from the Gunung Api volcano has buried signs of older settlements with a thick layer of volcanic tephra, making sites difficult or impossible to see during pedestrian survey. The islands are generally either covered in dense vegetation, or currently inhabited. Many of the late pre-colonial settlements very likely were re-occupied after the colonial conquest in 1621, and evolved into the currently occupied towns existing today. In response to these limitations, I attempted to locate a reasonably large sample of different settlement locales dating to the late pre-colonial era through various strategies. A total of twenty sites (defined as places of archaeological interest) were discovered by these means and subjected to test excavations, with the objective of identifying those sites with late pre-colonial period remains (Figure 2). Six sites had such remains, but due to time constraints, only four of those were excavated more extensively (BN1, BN2, BN4, and PA2). One additional site, PA1, was also excavated more extensively but dated to an earlier period (c. 3200 BP). Pedestrian survey was most productive on the outer island of Pulau Ay on land cleared for agriculture. In currently occupied towns, sites were located through non-systematic subsurface testing in areas where we could obtain local permission and which had reasonable security, such as the walled garden areas of Dutch colonial houses (sites PA2, PA3 and BB4, BB5 and BB6). Some sites were discovered because shoreline erosion had revealed older deposits in wave cut banks (such as site BN1). Site BN4, which was located on the 16th century shoreline, though now some 80 meters inland inside the walls of the former VOC governor's house, was located through subsurface testing, guided by a series of 18th- and 19th-century colonial period maps that documented shoreline progradation on southern Banda Naira. A limited experiment allowing local 
oral historians to guide site selection on Banda Besar was not archaeologically productive, although local informants often directed us to surface remains on Pulau Ay.

Cultural deposits were primarily midden deposits, composed of ceramics, metal and faunal remains. Sites on Banda Naira and Banda Besar were clearly stratified due to the regular deposition of culturally sterile volcanic tephra. In some cases, these tephra lenses could be linked to historically recorded volcanic eruption episodes. Excavation strategy was oriented to obtaining chronological data using small $(1 \times 1$ and $2 \times 2$ meter $)$ isolated block units, for a total of 4 - 11 square meters of excavated area per site. Test pits were used to identify site boundaries, and units were interspersed evenly across the site area, subject to the limitations of current use and geography of the sites. Generally, the built environment and intrasite structure remains poorly understood, though evidence for stone structures was encountered in some cases (see Lape 2000b). As is apparent, the archaeological data collected should not be considered a representative sampling of human use of the islands over time and space, and it is likely that conclusions about individual site use will change as larger areas are tested. However, the sites that were tested archaeologically do provide information about dates of occupation and abandonment, changes in settlement area, trade goods and foodways that allow at least a preliminary view of settlement patterning. Strata were dated with a series of radiocarbon dates and crosschecked with dateable Chinese ceramic tradeware assemblages.

\section{Synthesizing Different Lines of Evidence}

In several cases, the archaeological data showed areas of human settlement on the landscape that mapmakers did not depict on their maps. These "unmapped" settlements had some characteristic features. They were typically located in sections of the coastline that had poor boat access, particularly for large ships. They were exposed to prevailing winds and waves, were cut off from deep water by barrier reefs, and/or were situated on elevated terraces with steep drop-offs or cliffs leading down to the shore. These "forgotten" settlements were often out of sight of the central protected bay between Banda Naira, Banda Besar and Gunung Api Islands. In addition to these common geographic features, some of these unmapped settlements (and one settlement that was mapped, described below) also showed archaeological evidence of non-Islamic occupation. While all but one of the "mapped" settlements lacked remains of pig in their faunal assemblages, and were typically first occupied beginning in the 11th-12th centuries, unmapped settlements often had a longer occupation chronology (dating to the 5th century or earlier) and had substantial amounts of 
pig bones in pre-colonial contexts (although there is some variation, pig is generally not eaten by Muslims; see Insoll 1999; Reid 1993b; 1995). My interpretation of this pattern was that non-Islamic settlements in Banda were either invisible to European chroniclers or intentionally not recorded. European chronicles suggest that European traders had more contact and trade relationships with Muslim oriented settlements in Banda, despite the prevailing opposition to Islam that characterized the European colonial project in the East Indies.

A specific example of this pattern involves two settlements located on the island of Banda Naira, located on the north and south ends of the island. In textual sources, the two settlements are both identified in the earliest European maps and descriptions of the islands dating to the late 16th century. While the earliest descriptions of the two settlements suggest that they were of equivalent size and prominence in trade, by 1615 the northern settlement appeared to be declining in size and influence. The northern settlement (known by various similar names such as Labbetacca), is protected by a barrier reef, and completely disappears in post conquest (post 1621) maps, while the southern settlement (originally known as Nera, a name that later described the entire island) is located inside the protected Banda Bay and became the new colonial center, and is today the largest town and administrative center of the islands.

Seven square meters of archaeological site BN1, which appears to be the remains of Labbetacca, were excavated at various parts of the site. These excavations produced a faunal assemblage dominated by pig bones, distinctive earthenware pottery with incised decoration, remains of Chinese ceramics dating to the 10th century and possibly as early as the 5th century AD, and evidence for human cremation burials. A portion of the site was bounded by the remains of a coral block wall parallel to the shoreline that would have been at least 2 meters in height and 30-40 meters long during the 14th-16th centuries. The earliest occupation dated to the 5th century, with evidence of abandonment by the mid-17th century. The site is currently used as an agricultural field.

Two archaeological sites were located on the presumed locale of the settlement of Nera (BN2 and BN4), and a total of 15 square meters were excavated from the two sites. The earliest occupation levels dated to the 12th century AD, and the pre-colonial faunal assemblage was dominated by fish and completely lacked pig. These sites also lacked the distinctive decorated earthenware of site $\mathrm{BN} 1$, and there were no human remains found. Site BN2 also had a coral block wall parallel to the shoreline.

Following the synthesis of the archaeological and documentary evidence, the questions remained, what roles did apparently non-Islamic settlements such as Labbetacca play in the nutmeg trade economy and the Bandanese resistance to European colonial objectives? Why were they established earlier, in less acces- 
sible sections of the coast, and why did they disappear by the mid-17th century? My approach to answering these questions was to revisit the archival record to search for additional clues about divisions in Bandanese society that may have followed religious/ethnic lines. These clues were not apparent to me on the first reading of the texts. While some texts described factional splits and battles between different villages in Banda, the factions were described as political rather than religious in nature. Labbetacca and Nera were members of rival factions according to early Dutch chronicles. One description from the early 17th century describes a violent battle between the settlements and their allies (Tweede 1601: 32). However, a close reading of personal names and titles of village leaders, for example, revealed that so-called political divisions closely followed lines of religious identity that European chroniclers may not have been aware of, and that religion, ethnicity and politics were not necessarily separate categories for the Bandanese (Lape in press).

A deeper reading of this text and others that describe the two settlements reveals other clues. The names and political titles of men from Labbetacca recorded on Dutch treaty documents revealed that typical Bandanese Muslim political titles (such as Imam and Syabandar) were not used in Labbetacca. Other clues in regional oral traditions also suggest that Labbetacca was the more ancient center of political power, perhaps associated with pre-Islamic belief systems (Lape 2000b: 286-297).

In this case, textual and archaeological data were given equal interpretive weight and used in concert to generate hypotheses that were tested against each other. While limited and subject to considerable bias, when used together these data sets allowed for insights beyond what either could provide alone. In particular, archaeological patterns suggested a second reading of the texts, which in turn showed evidence for cultural processes that the original recorders of the text may not have noticed. It appears that internal divisions of Bandanese society followed religious lines, which overlaid geographical and historical lines. This suggests that Islamization in Banda was not all encompassing and instantaneous, but affected different settlements at different times. As discussed in other publications (Lape 2000a; 2000b; 2000c), 16th and early 17th-century documents also suggest that this uneven Islamization process caused significant conflict within Bandanese society, and that European colonizers were able to use these internal divisions to their advantage in the colonial conquest. The colonial conquest, in this interpretation, was not a simple matter of overwhelming Dutch military force overcoming an inferior Bandanese resistance, but rather the result of the long-term processes of Bandanese factionalization that had its origins in changing economic forces and the geography of belief. 


\section{FUTURE DIRECTIONS}

Despite the potential suggested by these examples, Island Southeast Asia continues to lag behind other regions in both the quantity of archaeological studies, and the integration of those studies into global theoretical concerns. Scholars have long called for improvements in this arena, and have demonstrated the clear need for more archaeological data (Bellwood 1997; Hutterer 1982; MacKnight 1986; Tanudirjo 1995). However, political unrest, bureaucratic obstacles to foreign research permission, lack of funding and institutional support for indigenous archaeologists, and lack of open exchange of theories and data between scholars in different disciplines have continued to limit the amount and the usefulness of historical archaeological research in the region. While it could be argued that historians have not been subject to these constraints, since their source data is in accessible archives in Southeast Asian capital cities or in Europe, it is likely that there are some documentary sources as yet untapped by historians in Asia with relevance to Island Southeast Asia. Oral history similarly has been underutilized, as both historians and archaeologists have struggled with its shifting and subjective meanings (Bowen 1989).

This review of historical archaeology in Island Southeast Asia, while not exhaustive, still suggests that there is considerable potential for new ways of combining textual and material data in the study of the past. Because Island Southeast Asia has been a cultural crossroads for so long, most of the region has been a part of the historical record of other places for more than a millennia, even if it lacked an indigenous written record in some earlier periods. Unlike the situation in North America, where early textual descriptions are almost universally from the point of view of European colonists, historic texts in Island Southeast Asia are written from a wide variety of cultural points of view and time periods, allowing for comparative analyses. Island Southeast Asia has not had as sharp an artificial disciplinary boundary between historic and prehistoric archaeology as North America has, and a greater proportion of archaeologists have straddled these periods. Finally, while there have been some abuses of the direct historical method and analogy, in general archaeologists have been careful to explicitly separate different lines of evidence in their analyses. The results, particularly in recent work in the region, have been advances in methods of combining multiple data sets that should see wider application, both in Island Southeast Asia and in other places. 


\section{BIBLIOGRAPHY}

Allen, Jane. 1991. "Trade and site distribution in early historic-period Kedah: Geoarchaeological, historic, and locational evidence." Bulletin of the Indo-Pacific Prehistory Association 10: 307-319.

Anderson, Benedict R.O.G. 1990. Language and Power: Exploring PoliticalCultures in Indonesia. Ithaca: Cornell University Press.

Andren, Anders. 1998. Between Artifacts and Texts: Historical archaeology in global perspective. New York: Plenum.

Bacus, Elisabeth. 1999. "Prestige and potency: Political economies of protohistoric Visayan polities." In Complex Polities in the Ancient Tropical World, edited by E.B. a. L. Lucero, 67-87. Washington: American Anthropological Association.

Beaudry, M., L. Cook, and S. Mrozowski. 1991. "Artifacts and active voices: Material culture as social discourse." In The Archaeology of Inequality, edited by R. McGuire and R. Paynter, 150-191. London: Basil Blackwell.

Bellwood, Peter. 1997. Prehistory of the Indo-Malaysian Archipelago. Honolulu: University of Hawaii Press.

Binford, Lewis. 1962. "Archaeology as anthropology." American Antiquity 28: 217-225.

Bintliff, J. 1991. The Annales School and Archaeology. Leicester: Leicester University Press.

Bowen, John R. 1989. "Narrative form and political incorporation: Changing uses of history in Aceh, Indonesia." Society for Comparative Study of Society and History 31: 671-93.

Boyd, M., J.C. Erwin, and M. Hendrickson. 2000. The Entangled Past: Integrating History and Archaeology. Calgary: The Archaeological Association of the University of Calgary.

Bulbeck, David F. 1992. "A Tale of Two Kingdoms: The historical archaeology of Gowa and Tallok, South Sulawesi, Indonesia." Ph.D. dissertation, Department of Archaeology and Anthropology, The Australian National University, Canberra.

Bulbeck, F. David and Bagyo Prasetyo. 2000. "Two millennia of socio-cultural development in Luwu, South Sulawesi, Indonesia." World Archaeology 32: 121-137.

Caldwell, Ian. 1995. "Power, state and society among the pre-Islamic Bugis." Bijdragen tot de Taal- Land-en Volkenkunde 151: 394-421.

Champion, T.C. 1990. "Medieval archaeology and the tyranny of the historical record." In From the Baltic to the Black Sea: Studies in medieval archaeology, edited by D. Austin and L. Alcock, 79-95. London: Unwin Hyman.

Clarke, Anne, and Robin Torrence. 2000. The Archaeology of Difference: Negotiating Crosscultural Engagements in Oceania. New York: Routledge.

Clarke, David. 1973. "Archaeology: the loss of innocence." Antiquity 47: 6-18.

Coedés, G. 1968. The Indianized States of Southeast Asia. Honolulu: East-West Center Press.

Cortesão, Armando and Avelino Teixeira da Mota. 1987. Portugaliae Monumenta Cartographica. Lisboa: Imprensa Nacional-Casa da Moeda.

Cusick, James G. 1998a. "Historiography of acculturation: An evaluation of concepts and their application in archaeology." In Studies in Culture Contact: Interaction, Culture Change and Archaeology, Occasional Paper No. 25, edited by J.G. Cusick, 126-145. Carbondale: Center for Archaeological Investigations, Southern Illinois University.

- 1998b. Studies in Culture Contact: Interaction, Culture Change and Archaeology, Occasional Paper No. 25. Carbondale: Center for Archaeological Investigations, Southern Illinois University.

Deagan, K. 1988. "Neither history nor prehistory: The questions that count in historical archaeology." Historical Archaeology 22: 7-12.

Description. 1598. The Description of a Voyage Made by Certain Ships of Holland into the East Indies, With their Adventutres and Successe, April 1595-Aug 1597. Translated by t. f. t. D. b. W. Phillip. London. 
Edwards McKinnon, E. 1984. "Kota Cina: Its context and meaning in the trade of Southeast Asia in the twelth to fourteenth centuries." Doctoral dissertation, Department of the History of Art, Cornell University.

Faubion, James D. 1993. "History in anthropology." Annual Review of Anthropology 22: 35-54.

Feener, R. Michael. 1998. "A Re-Examination of the Place of al-Hallaj in the Development of Southeast Asian Islam.” Bijdragen tot de Taal- Land-en Volkenkunde: 571-592.

Feinman, Gary. 1997. "Thoughts on new approaches to combining the archaeological and historical records." Journal of Archaeological Method and Theory 4: 367-377.

Ferguson, Leland G. 1992. Uncommon Ground: Archaeology and early African America, 1650-1800. Washington: Smithsonian Institution Press.

Fish, Suzanne K., and Stephen A. Kowalewski. 1990. The Archaeology of Regions: A case for full-coverage survey. Washington: Smithsonian Institution Press.

Fisher, Robin, and Hugh Johnston. 1993. From Maps to Metaphors. Vancouver: University of British Columbia Press.

Flannery, Kent. 1972. "Culture history vs. culture process: A debate in American archaeology." In Contemporary Archaeology, edited by M. Leone. Carbondale: Southern Illinois University Press.

Funari, Pedro Paulo A., Sian Jones and Martin Hall. 1999. Historical Archaeology: Back from the Edge. New York: Routledge.

Galloway, Patricia Kay. 1995. Choctaw genesis, 1500-1700. Lincoln: University of Nebraska Press.

Geertz, Clifford. 1960. The Religion of Java. New York: The Free Press of Glencoe.

Glover, Ian C. 1990. Early Trade Between India and South-East Asia, A Link in the Development of a World Trading System, Occasional Paper No. 16. Hull: Centre for East Asian Studies, University of Hull.

Godsen, Chris. 1999. Anthropology and Archaeology: A changing relationship. New York: Routledge.

Hall, Kenneth R. 1985. Maritime Trade and State Development in Early Southeast Asia. Honolulu: University of Hawaii.

Hall, Martin. 2000. Archaeology and the Modern World: Colonial transcripts in South Africa and the Chesapeake. New York: Routledge.

Hanna, Willard Anderson. 1978. Indonesian Banda: Colonialism and its aftermath in the Nutmeg Islands. Philadelphia: Institute for the Study of Human Issues.

Harley, J.B. 1992. "Deconstructing the map." In Writing Worlds: Discourse, texts, and metaphors in the representation of landscape, edited by T.J. Barnes and J.S. Duncan, 231-247. London: Routledge.

Harley, J.B., and David Woodward. 1987. Cartography in Prehistoric, Ancient, and Medieval Europe and the Mediterranean, vol. 1. Chicago: University of Chicago Press.

Hooker, M.B. 1983. Islam in South East Asia. Leiden: Brill.

Hutterer, Karl. 1982. "Early Southeast Asia: Old wine in new skins? A review article." Journal of Asian Studies 61: 559-570.

Insoll, Timothy. 1996. Islam, Archaeology and History: Gao Region (Mali) ca. AD 900-1250. Oxford: Tempvs Reparatvm.

- 1999. The Archaeology of Islam. Oxford: Blackwell.

Johns, Anthony H. 1995. "Sufism in Southeast Asia: Reflections and reconsiderations." Journal of Southeast Asian Studies 26: 169-183.

Junker, Laura. 1993. "Craft goods specialization and prestige goods exchange in Philippine chiefdoms of the fifteenth and sixteenth centuries." Asian Perspectives 32: 1-35.

- 1994. "Trade competition, conflict, and political transformations in sixth- to sixteenthcentury Philippine chiefdoms." Asian Perspectives 33: 229-259.

1996. "Hunter-gatherer landscapes and lowland trade in the prehispanic Philippines." World Archaeology 27: 389-410.

- 1998. "Integrating history and archaeology in the study of contact period Philippine chiefdoms." International Journal of Historical Archaeology 2: 291-320. 
1999. Raiding, Trading, and Feasting: The political economy of Philippine chiefdoms. Honolulu: University of Hawai'i Press.

Kepecs, Susan. 1997. "Introduction to new approaches to combining the archaeological and historical records." Journal of Archaeological Method and Theory 4: 193-198.

Kirch, P.V., and Marshall Sahlins. 1992. Anahulu: The Anthropology of History in the Kingdom of Hawaii. Vol. 2: The Archaeology of History. Chicago: University of Chicago Press.

Knapp, A. Bernard. 1992. Archaeology, Annales, and Ethnohistory. Cambridge: Cambridge University Press.

Kolb, Michael. 1997. "Labor mobilization, ethnohistory and the archaeology of community in Hawai'i." Journal of Archaeological Method and Theory 4: 265-286.

Kowalewski, Stephen. 1997. "A spatial method for integrating data of different types." Journal of Archaeological Method and Theory 4: 287-306.

Kulke, H. 1990. "Indian colonies, Indianization or cultural convergence? Reflections on the changing image of India's role in South-East Asia." In Onderzoek in Zuidoost-Azie: Agenda's voor de Jaren Negentig, edited by H.S. Nordholt, 8-32. Leiden: Rijksuniversiteit te leiden, Vakgroep Talen en Culturen van Zuidoost-Azie en Oceanie.

Kus, Susan. 1997. "Archaeologists as anthropologists: Much ado about something after all?" Journal of Archaeological Method and Theory 4: 199-214.

Lape, Peter V. 2000a. "Contact and colonialism in the Banda Islands, Maluku, Indonesia." Bulletin of the Indo-Pacific Prehistory Association 20: 48-55.

—. 2000b. "Contact and Conflict in the Banda Islands, Eastern Indonesia, 11th-17th Centuries."

Ph.D. Dissertation, Department of Anthropology, Brown University, Providence.

—. 2000c. "Political Dynamics and Religious Change in the Late Pre-colonial Banda Islands, Eastern Indonesia." World Archaeology 32.

—. in press. "Historic maps and archaeology as a means of understanding late pre-colonial settlement in the Banda Islands, Indonesia." Asian Perspectives.

Last, Jonathan. 1995. "The nature of history." In Interpreting Archaeology: Finding Meaning in the Past, edited by I. Hodder, M. Shanks, A. Alexandri, V. Buchli, J. Carman, J. Last, and G. Lucas, 141-157. New York: Routledge.

Layton, Robert. 1989. Conflict in the Archaeology of Living Traditions. New York: Routledge.

Leone, Mark, and Parker Potter. 1988. The Recovery of Meaning: Historical archaeology in the Eastern United States. Washington: Smithsonian Institution Press.

Lightfoot, Kent. 1995. "Culture contact studies: Redefining the relationship between prehistoric and historical archaeology." American Antiquity 60: 199-217.

Loth, Vincent. 1995a. "Armed incidents and unpaid bills: Anglo-Dutch rivalry in the Banda Islands in the seventeenth century." Modern Asian Studies 29: 705-740.

— 1995b. "Pioneers and Perkeniers: The Banda Islands in the 17th century." Cakalele 6: $13-35$.

- 1998. "Fragrant gold and food provision: Resource management and agriculture in seventeenth century Banda." In Old World Places, New World Problems: Exploring Issues of Resource Management in Eastern Indonesia, edited by S. Pannell and F.V. BendaBeckmann. Canberra: Australian National University.

MacKnight, C.C. 1986. "Changing perspectives in Island Southeast Asia." In Southeast Asia in the 9th to 14th Centuries, edited by D.G. Marr and A.C. Milner, 215-227. Singapore: Institute of Southeast Asian Studies.

Masselman, George. 1963. The Cradle of Colonialism. New Haven: Yale University Press.

McBride, Terry, and Beth Rudden. 2000. "Where are all the myths? Native American oral traditions and their place in archaeological inference." In The Entangled Past: Integrating History and Archaeology, edited by M. Boyd, J.C. Erwin, and M. Hendrickson, 330-335. Calgary: The Archaeological Association of the University of Calgary.

Miksic, John. 1999. "Water, urbanization and disease in ancient Indonesia." In Complex Polities in the Ancient Tropical World, edited by E.B. a. L. Lucero, 167-184. Washington: American Anthropological Association. 
— 2000. "Heterogenetic cities in premodern Southeast Asia." World Archaeology 32: 106120.

Miller, Daniel. 1980. “Archaeology and development." Current Anthropology 21: 709-726.

Milner, A.C. 1983. "Islam and the Muslim state." In Islam in South East Asia, edited by M.B. Hooker, 23-49. Leiden: Brill.

Morrison, Kathleen, and Mark Lycett. 1997. "Inscriptions as artifacts: Precolonial South India and the analysis of texts." Journal of Archaeological Method and Theory 4: 215-238.

Moser, S. 1995. "The "Aboriginalization" of Australian archaeology." In Theory in Archaeology: A world perspective, edited by P.J. Ucko. London: Routledge.

Nakamura, Hiroshi. 1963. East Asia in Old Maps. Honolulu: East West Center Press.

Orser, Charles. 1994. "Towards a global historical archaeology: An example from Brazil." Historical Archaeology 28: 5-22.

- 1996. A Historical Archaeology of the Modern World. New York: Plenum Press.

Pires, Tomé, and Francisco Rodrigues. 1944. The Suma Oriental of Tomé Pires, An account of the East, from the Red Sea to Japan, written in Malacca and India in 1512-1515, and The book of Francisco Rodrigues, rutter of a voyage in the Red Sea, nautical rules, almanack and maps, written and drawn in the East before 1515. Translated by A. Cortesão. London: The Hakluyt Society.

Raffles, Thomas Stamford. 1817. The History of Java. London: Printed for Black Parbury and Allen Booksellers to the Hon. East-India Company ... and John Murray.

Ray, Himanshu Prabha. 1989. "Early maritime contacts between South and Southeast Asia." Journal of South East Asian Studies 20: 42-54.

Reid, Anthony. 1993a. "Islamization and Christianization in Southeast Asia: The critical phase, 1550-1650." In Southeast Asia in the Early Modern Era: Trade, power, and belief, edited by A. Reid, 151-179. Ithaca, N.Y.: Cornell University Press.

—. 1993b. Southeast Asia in the Early Modern Era: Trade, power, and belief. Ithaca, N.Y.: Cornell University Press.

- 1995. "Continuity and change in the Austronesian transition to Islam and Christianity." In The Austronesians: Historical and Comparative Perspectives, edited by P. Bellwood, J. Fox, and D. Tryon, 314-331. Canberra: Australian National University.

Ricklefs, M.C. 1993. A History of Modern Indonesia Since c. 1300. London: Macmillan.

- 1979. "Six centuries of Islamization in Java." In Conversion to Islam, edited by N. Levtzion, 100-128. New York: Holmes and Meier.

Rockhill, W.W. 1915. "Notes on the relations and trade of China with the Eastern Archipelago and the coast of the Indian Ocean during the fourteenth century, part II." T'oung Pao 26: 61-626.

Rogers, J. Daniel, and Samuel M. Wilson. 1993. Ethnohistory and Archaeology: Approaches to postcontact change in the Americas. New York: Plenum Press.

Rowlands, Michael. 1998. "The Archaeology of Colonialism." In Social Transformations in Archaeology: Global and local perspectives, edited by K. Kristiansen and M. Rowlands. New York: Routledge.

Rubertone, Patricia. 1989. "Archaeology, colonialism and 17th century Native America: Towards an alternative explanation." In Conflict in the Archaeology of Living Traditions, edited by R. Layton, 32-45. New York: Routledge.

Schmidt, Peter, and Thomas Patterson. 1995. Making Alternative Histories: The practice of archaeology and history in non-Western settings. Santa Fe: School of American Research.

Schrieke, Bertram Johannes Otto. 1960. Indonesian Sociological Studies: Selected writings. Bandung: Summur Bandung.

Schuyler, Robert. 1978. Historical Archaeology: A guide to substantive and theoretical contributions. Farmingdale, New York: Baywood Publishing.

— 1988. "Archaeological remains, documents and anthropology: A call for a new culture history." Historical Archaeology 22: 36-44.

Scott, Elizabeth M. 1994. Those of Little Note: Gender, Race, and Class in Historical Archaeology. Tucson: University of Arizona Press. 
Skowronek, Russell K. 1998. "The Spanish Philippines: archaeological perspectives on colonial economics and society." International Journal of Historical Archaeology 2: 45-71.

Sollewijn Gelpke, J.H.F. 1995. "Alfonso de Albuquerque's pre-Portuguese 'Javanese' map, partially reconstructed from Francisco Rodrigues' Book." Bijdragen tot de Taal- Land-en Volkenkunde 151: 76-99.

South, Stanley. 1977. Method and Theory in Historical Archaeology. New York: Academic Press.

Stahl, Ann Brower. 2001. Making History in Banda: Anthropological visions of Africa's past. New York: Cambridge University Press.

Suarez, Thomas. 1999. Early Mapping of Southeast Asia. Hong Kong: Periplus Editions.

Tanudirjo, Daud A. 1995. "Theoretical trends in Indonesian archaeology." In Theory in Archaeology: A world perspective, edited by P.J. Ucko, 61-75. London: Routledge.

Thurston, Tina. 1997. "Historians, prehistorians, and the tyranny of the historical record: Danish state formation through documents and archaeological data." Journal of Archaeological Method and Theory 4: 239-264.

Tibbetts, G.R. 1979. A study of the Arabic texts containing material on South-East Asia, Edited by B. Royal Asiatic Society of Great, Ireland, and F. Oriental Translation. Leiden: E.J. Brill for the Royal Asiatic Society.

Trigger, Bruce. 1984. "Archaeology at the crossroads: What's new?" Annual Review of Anthropology 13: 275-300.

- 1989. A History of Archaeological Thought. Cambridge: Cambridge University Press.

Trouillot, Michel-Rolph. 1995. Silencing the Past: Power and the production of history. Boston: Beacon Press.

Tweede. 1601. Het Tvveede Boeck, journael oft dagh-register, inhoudende een warachtich verhael ende historische vertellinghe vande reyse, gedaen door de acht schepen van Amstelredamme, gheseylt inden maent martij 1598. onder 'tbeleydt vanden Admirael Iacob Cornelisz. Neck, ende Wybrant van VVarvvijck als vice-admirael.... Met . . een vocabulaer van hare woorden. Middelburg: Barent Langhenes.

Valentijn, François. 1724. Oud en Nieuw Oost-Indien, Vervattende een naaukeurige en uitvoerige verhandelinge van Nederlands mogentheyd in die gewestenk, benevens eene wydluftige beschryvinge der Moluccos, 5 volumes. Dordrecht: J. van Braam.

van der Chijs, J.A. 1886. De Vestiging van het Nederlandische Gezag over de BandaEilanden (1599-1621). Batavia: Albrecht and Co.

van Leur, J.C. 1967. Indonesian trade and society: essays in Asian social and economic history. The Hague: W. van Hoeve.

Wall, Victor Ido van de. 1928. De Nederlandsche Oudheden in de Molukken. 'S Gravenhage: Martinus Nijhoff.

Winer, Margot. 1995. "The painted, poetic landscape: Reading power in nineteenth-century textual and visual representations of the Eastern Cape frontier." Kroeber Anthropological Society Papers 79: 74-109.

Wisseman Christie, Jan. 1995. "State formation in early maritime Southeast Asia: A consideration of the theories and the data." Bijdragen tot de Taal-Land-en Volkenkunde 151: 235-288.

Wolters, O.W. 1974. Early Indonesian Commerce: A study of the origins of Srivijaya. Ithaca. N.Y.: Cornell University Press.

- 1999. History, Culture, and Region in Southeast Asian Perspectives. Ithaca, NY: Southeast Asia Program Publications, Cornell University.

Young, T.C. 1988. "Since Herodotus, has history been a valid concept?" American Antiquity 53: 7-12.

Zandvliet, Kees. 1998. Mapping for Money: Maps, plans and topographic paintings and their role in the Dutch overseas expansion during the 16th and 17th centuries. Amsterdam: Batavian Lion International. 